\title{
Phylogenetic Analysis of Endemic Fish from the Maros Karst Region, South Sulawesi, Indonesia
}

\author{
Sharifuddin Bin Andy Omar ${ }^{*}$, Andi Aliah Hidayani ${ }^{1}$, Dewi Yanuarita ${ }^{1}$, Moh Tauhid Umar ${ }^{1}$ and Sapto Andriyono ${ }^{2}$ \\ ${ }^{1}$ FisheriesDepartment, Faculty of Marine Science and Fisheries, Hasanuddin University, South Sulawesi, 90245, Indonesia \\ ${ }^{2}$ Department of Marine, Fisheries and Marine Faculty, Universitas Airlangga, East Java, 60115, Indonesia \\ *For correspondence: sharifuddin@unhas.ac.id \\ Tontributed equally to this work and are co-first authors
}

Received 26 June 2021; Accepted 20 September 2021; Published 15 December 2021

\begin{abstract}
The Maros Karst is known for having a unique geomorphological structure with a diversity of endemic flora and fauna. The hydrology of this karst area is generally dominated by underground rivers with various freshwater ecosystems, which are generally dominated by endemic fish typical to Sulawesi. This study aims at identifying endemic fish of Maros Karst rivers using morphological and phylogenetic analysis as the baseline for further endemic fish conservation. Morphological analysis was done by comparing fish samples' morphological characteristics with those from fish taxonomy references. Phylogenetic analysis was carried out using mitochondrial DNA (mtDNA) analysis with the target gene Cytochrome C oxidase 1 (CO1). The results showed there are five endemic fish species from four families and three orders from the Maros Karst area with a genetic distance value between 0.0 to 0.275 . These species make particular adaptations both morphologically and genetically to the karst ecosystem. However, it is necessary to understand the evolution of these fishes to establish effective conservation measures. Therefore, it is necessary to have a management strategy to ensure the sustainability of endemic fish populations and as well as the sustainability of the karst ecosystem as a whole. (C) 2021 Friends Science Publishers
\end{abstract}

Keywords: Maros Karst area; Endemic fish; Morphology; Phylogenetic; CO1

\section{Introduction}

The Maros Karst, known also as The Maros-Pangkep Karst, is an area that develops explicitly from the process of dissolving carbonate rocks (limestone and dolomite) within a specific time (Achmad and Hamzah 2016). According to Taslim (2014), Maros Karst area is unique, consisting of hills, valleys, dolina, uvala, polje, river systems and underground river networks and forests with different soil surface textures and compositions at each altitude, resulting uniqueness of the biota living in that karst area (Suhendar et al. 2018). According to Achmad and Hamzah (2016), this karst is one of the largest and second most beautiful karst in the world after the karst in China.

The Maros-Pangkep Karst is located in the Bantimurung-Bulusaraung National Park, which is known as one of the best conical karst areas in the world. This karst has a unique geomorphological form with a diversity of endemic flora and fauna (Putri et al. 2020). Endemic species is an organism whose distribution is limited in scope and is only found in one particular area (Omar 2012; Dekić et al. 2015). The limited distribution and abundance of endemic species in a region allow knowledge of the rate of evolution such as area, age, isolation and environment (Hanly et al.
2017). Karst areas are highly fragmented habitats and could become a primary candidate for conservation due to their diversity and high levels of endemism (Çiçek et al. 2018), limited food sources, living under intense selective pressure and in natural isolation (Bichuette and Trajano 2015). The hydrology of the Maros Karst area is generally dominated by underground rivers (subsurface drainage). This condition is caused by the entry of rainwater through fractures which then concentrates and forms subsurface channels (Taslim 2014) forming Bantimurung River Watershed (Arsyad et al. 2014). Like other karst rivers, freshwater ecosystems within the karst are threatened with extinction because the permeability of the rocks could not filter well enough the contaminants from human, animal and industrial waste (Kolda et al. 2020). According to Omar et al. (2020) there are seven species of endemic fish in this karst need to be managed strategically to ensure the sustainability of those fish population as well as the watershed ecosystem as a whole.

The accuracy of species identification is necessary for fisheries management and conservation (Abdulmalik-Labe and Quilang 2019). Morphological and phylogenetic analysis is adequate tools for verifying species identity (Bayot et al. 2014). According to Serdiati et al. (2020), fish

To cite this paper: Omar SBA, AA Hidayani, D Yanuarita, MT Umar, S Andriyono (2021). Phylogenetic analysis of endemic fish from the Maros Karst region, south Sulawesi, Indonesia. Intl J Agric Biol 26:661-666 
morphological characters such as body shape, colour pattern, and the number of scales is used as an initial method to distinguish species. In accordance with phylogenetic ichthyofauna in the Maros Karst rivers, based on literature search, the information on this particular topic is still lacking. Out of seven endemic species of this area, our preliminary observation found only three species: Marosatherina ladigesi, Lagusia micracanthus and Oryzias celebensis. Several ichthyofauna studies that have been done were on $M$. ladigesi, related to its morphology such as taxonomic status (Hadiaty 2007); sexual dimorphism, colour patterns, habitat and distribution (Hadiaty 2017); reproductive biology (Omar et al. 2014; Kariyanti et al. 2019; Nasyrah et al. 2020); eco-biology (Nasyrah et al. 2019); genetics (Jayadi et al. 2015) and the length-weight relationship (Omar et al. 2020). More research was also done on L. micracanthus on the fish description and historical tracing (Hadiaty 2012; Vari and Hadiaty 2012), reproductive biology (Andy Omar et al. 2015; Nur et al. 2016), morphometrics (Nur et al. 2020a) and length-weight relationship (Nur et al. 2020b). As for O. celebensis, the research covered its gonad development (Hamaguchi 1983) and reproductive biology (Hasanah et al. 2019).

However, species identification through morphological analysis is complicated and considered subjective in deciding a species within the same genus; therefore, the current molecular approach using DNA barcode is preferably done to strengthen the morphological approach. The DNA barcoding is carried out by utilizing mitochondrial DNA as a basis for observing variations, kinship in species and studies related to genetics (Bucklin et al. 2010). Mitochondrial DNA (mtDNA) has become one of the most common molecular markers and used for phylogenetic and taxonomic studies in animals because of maternal inheritance. Although mtDNA sequencing data successfully determine the phylogenetic relationships, there are considerable differences in the characteristics of the various gene types and of great importance. Cytochrome c oxidase subunit I (COI) is the largest of the mtDNA cytochrome oxidase subunits (Clark et al. 2010). It is one of the largest protein-coding genes in the metazoan mitochondrial genome, which has been used as a target gene for molecular phylogenetic and identification studies (Naim et al. 2012).

According to Hebert et al. (2003), analysis of variations in $\mathrm{CO} 1$ sequences is an analytical method that has a high diversity and is very useful in determining the relatedness of species. Subunit 1 cytochrome oxidation was chosen because it is the most stable gene and its relatively fast evolution rate when compared to other genes in mtDNA (Bucklin et al. 2010). Besides, CO1 is also considered capable of differentiating between individuals at the species level (Lefébure et al. 2006). Cytochrome c oxidase subunit 1 PCR has been used by several researchers to identify freshwater fish in Lake Towuti, South Sulawesi (Larson et al. 2014) and managed to identify a new species of goby fish, while Jayadi et al. (2019) successfully identified endemic fish of the Termatherinidae family using PCR Cytochrome c Oxidase 1. Inadequate information on fish species identification, morphologically and phylogenetically, in Maros Karst became our research rationale to identify endemic species using CO1 target gene with the hope for baseline data in fish endemic conservation.

\section{Materials and Methods}

\section{Sampling site and collection}

A total of 15 fish samples were collected from three rivers (Batubassi, Bantimurung, and Pattunuang) of the Maros Karst, South Sulawesi, Indonesia (Fig. 1) from July to December 2020. Morphological identification was conducted according to the guideline from Kottelat et al. (1993) and Hadiaty (2012), prior to DNA analysis. Each individual fish sample was photographed using a digital camera. Species then confirmed through molecular identification using the $\mathrm{CO} 1$ gene region. In addition, $50 \mathrm{mg}$ of anal fin tissues from each sample was preserved with $70 \%$ alcohol solution. Before the DNA extraction process, the collected samples were stored at room temperature.

\section{DNA extraction, PCR and data analysis}

DNA extraction was done using genomic DNA mini kit (Geneaid). Genetic analysis was performed using Cytochrome c Oxidase Subunit 1 (CO1) with FISH-BCL (5'TCA ACY AAT CAY AAA GAT ATY GGC AC) and FISH-BCH (5'-TAA ACT TCA GGG TGA CCA AAA AAT CA) primers referred to Baldwin et al. (2009) and Andriyono et al. (2020). CO1 gene amplification was conducted using PCR with initial denaturation program at a temperature of $95^{\circ} \mathrm{C}$ for 5 min following 40 cycles consisting of denaturation at $95^{\circ} \mathrm{C}$ for $30 \mathrm{~s}$, annealing at $50^{\circ} \mathrm{C}$ for $30 \mathrm{~s}$, extension at $72^{\circ} \mathrm{C}$ for $45 \mathrm{~s}$ and a final extension at $72^{\circ} \mathrm{C}$ for 5 min. The PCR amplification product was then separated using electrophoresis of $1 \%$ agarose gel. A DNA fragment from agarose gel was documented using the Gel Documentation System (Biometra). Finally, the size of the DNA fragment was then measured using a 100 bp Plus DNA Ladder. DNA sequencing was performed at PT Genetics Science in Jakarta as a private agent. Gene purification and sequencing were carried out at 1st Base in Malaysia. The PCR product was $20 \mu \mathrm{L}$ and the total primer was $150 \mu \mathrm{L}$.

DNA sequence data were used for forward and reverse primers which were put together or aligned using BioEdit7 software. The BLAST (Basic Local Alignment Search Tool) analysis at http://www.ncbi.nih.nlm.gov/BLAST (Madden 2013) was carried out on DNA sequences from each fish sample to determine its similarity to DNA COI sequences in the GenBank database. Accessions were of high similarity, and sequences were downloaded to make phylogenetic trees using the MEGA (Molecular Evolutionary Genetics Analysis) version 7.0 program (Kumar et al. 2016). 


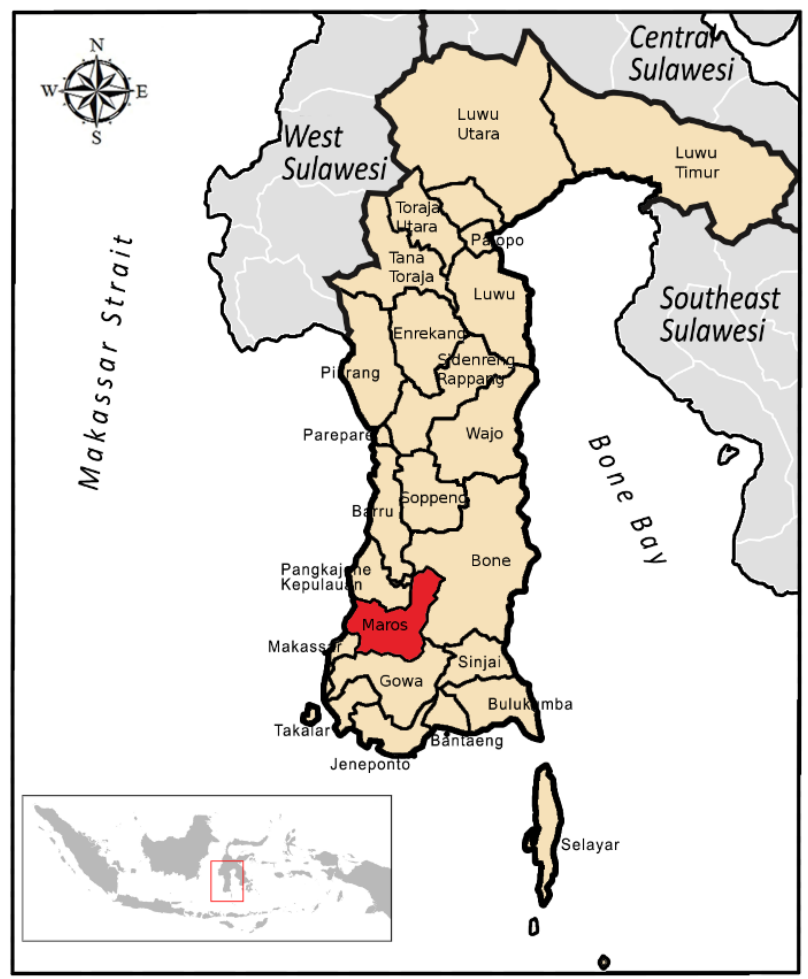

Fig. 1: Map showing study sites from where fishes were collected

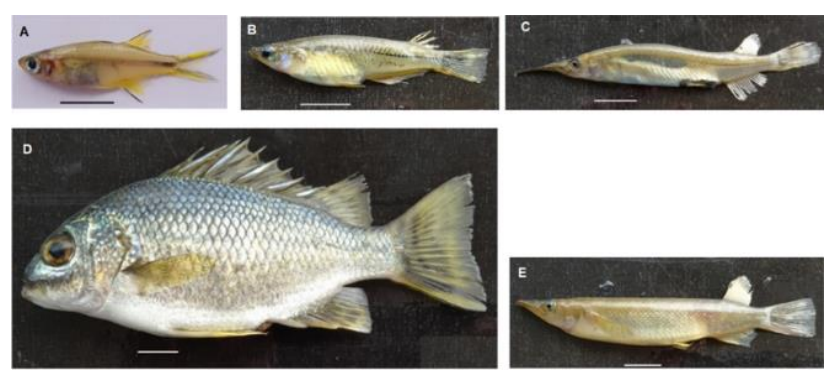

Fig. 2: Endemic fish found in the Maros Karst Region. (A) Marosatherina ladigesi (Ahl 1936); (B) Oryzias celebensis (Weber 1894); (C) Dermogenys orientalis (Weber 1894); (D) Lagusia micracanthus (Bleeker 1860) and (E) Nomorhamphus liemi (Vogt 1978); scale bar $1 \mathrm{~cm}$

\section{Results}

A total of $15 \mathrm{CO} 1$ samples were obtained from 5 endemic fish species originating from the karst region representing 5 genera, 4 families and 3 orders (Table 1 and Fig. 2). Of the five genera of these endemic fish, the $\mathrm{CO} 1$ sequence that represents these fish in the gene bank is only three genera, namely $M$. ladigesi (1 sequence), $N$. liemi (1 sequence) and O. celebensis (2 sequences). Two other fish species have not been registered in the genbank sequence, namely $D$. orientalis and L. micracanthus.

Furthermore, gene sequencing of these endemic fish samples, especially $M$. ladigesi and $O$. celebensis, showed

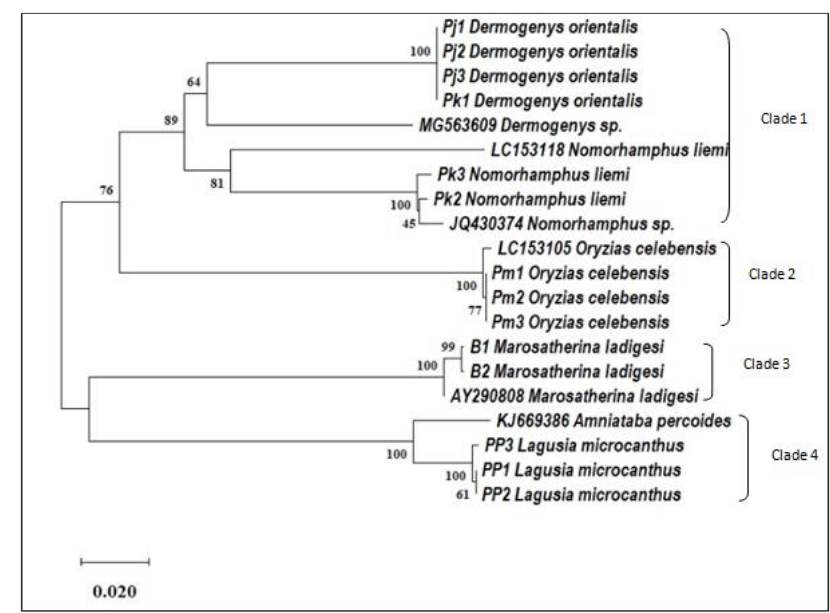

Fig. 3: Phylogenetic tree of Maros Karst's endemic fish by Maximum Likelihood method

similarities with similar fish sequences registered in the gene bank (Fig. 3), namely M. ladigesi (Accession No.: AY 290808.1) with a $97.09 \%$ similarity with the sample sequence we obtained, as well as $O$. celebensis (Accession No.: LC153105.1) with a 95-96\% similarity to our sample sequence. For $N$. liemi fish, it has a similarity with the sample sequence $N$. liemi (Accession No.: LC1533118.1) of 85.78\% and Nomorhampus spp. (Accession No.: JQ430374) of $95 \%$.

\section{Discussion}

Phylogenetic trees using the Maximum Likelihood method produced four clades based on family groups. Clade II to clade IV showed each species genetics, except for clade I, which grouped two species, namely $N$. liemi and $D$. orientalis. Phylogenetic analysis shows that these two species are genetically closely related, although they have differences in morphology. They are still in one family, namely Zenarchopteridae. Apart from these two species, species $O$. celebensis in clade III also shows a kinship relationship with $N$. liemi and $D$. orientalis, because $O$. celebensis is still in the same order as the two species, namely Beloniformes.

According to Kobayashi et al. (2020), the order Beloniformes is divided into five families, namely Belonidae (having an elongated upper and lower jaw), Hemiramphidae (fish that have beaks), Zenarchopteridae (having beaks with viviparous reproductive characteristics), Exocoetidae (flying fish) and Adrinichthyidae (rice fish). Hemirhamphidae and Zenarchopteridae only have elongated mandibles, while Exocoetidae and Adrinichthyidae have non-elongated upper and lower jaws. However, in this study, we only found endemic fish that belong to two families, namely Zenachopteridae and Adrinichthyidae. In addition to the relationship between clade I and clade II, clade IV (M. ladigesi) shows almost the same reproductive 
Table 1: Types of endemic fish caught in the Maros Karst Area

\begin{tabular}{|c|c|c|c|c|c|}
\hline Order & Family & Species & Common name & Indonesian name & Local name \\
\hline Atheriniformes (1.6\%) & Telmatherinidae & Marosatherina ladigesi (Ahl 1936) & Celebes rainbowfish & Ikan pelangi Maros & Beseng-beseng \\
\hline \multirow[t]{3}{*}{ Beloniformes $(0.3 \%)$} & Adrianichthyidae & Oryzias celebensis (Weber 1894) & Celebes medaka & & Binishi \\
\hline & Zenarchopteridae & Dermogenys orientalis (Weber 1894) & & Ikan julung-julung & Anculung \\
\hline & & Nomorhamphu: & & & Anculung \\
\hline Perciformes $(0.5 \%)$ & Terapontidae & Lagusia micracanthus (Bleeker 1860) & & & Piri' \\
\hline
\end{tabular}

characteristics as clade I and clade II, namely having unique types of testes and ovaries, which in turn affect reproductive modifications such as spermatogenesis, internal fertilization, hermaphrodites, and viviparity (Malabarba and Malabarba 2020). The L. micracanthus (Clade III) is the only distinct endemic species in South Sulawesi (Vari and Hadiati 2012). The only fish from the Terapontidae family that lives in freshwaters with distribution is limited to certain rivers in South Sulawesi (Nur et al. 2020a). This finding suggests that phylogenetic trees can describe the relationship between clades and taxonomic groups (Alotaibi et al. 2020).

Phylogenetic trees can also explain the evolutionary relationships between individuals or groups of organisms, which initially use morphological characteristics, based on similarities and are considered to have a close kinship. However, classical systematic analysis is sometimes confusing due to environmental variables, so that the use of proteins and DNA characters is developed to infer the phylogenetic relationship (Samsudin 2017).

Mitochondrial DNA analysis that is commonly used to classify and identify fish is the cytochrome 1 (CO1) subunit. The CO1 gene is a highly conserved region that has been used at all levels of organisms to identify species, differing only by a few sequences (variable locations) (Serdiati et al. 2020). According to In et al. (2013), universal primers for the $\mathrm{CO} 1$ gene are very stable and attach to the $5^{\prime}$ end of the animal gene. The CO1 gene has advantages over other mitochondrial genes such as cytochrome $b$ because changing the amino acid sequence is slower in evolution. The application of the $\mathrm{CO} 1$ gene in identifying species is called a DNA barcode (Samsudin 2017). DNA barcode is very relevant to use in habitats that have a diversity of species that are threatened with extinction due to anthropogenic activities (Hubert et al. 2016), such as in karst areas.

The karst area is one of the most fragmented habitats, and limited food sources (Bichuette and Trajano 2015), causing organisms in the ecosystem to adapt specifically and depend on the karst environment (Putri et al. 2020). These organisms have the potential to be specialized resources and could create ecological opportunities for exploration of tropical organisms and promote greater species diversity (Hanly et al. 2017).

The results of molecular analysis indicate that in general, the endemic fish groups based on species in this karst area are monophyletic (or having a common ancestor). Due to a geographic barrier, the distribution of these fish is limited, except for $D$. orientalis, which is paraphyletic (the ancestors are the same, but not all individuals belong to the same clade). This phenomenon is also explained by Samsudin (2017), that $D$. orientalis are paraphyletic based on histological analysis of the gonads and embryonic modifications and osteological characteristics. Unlike the case with $D$. orientalis, $N$. liemi is monophyletic. Although it can be seen in Fig. 3, there is one individual $N$. liemi in the subclade $D$. orientalis, similar to that found by Bruyn et al. (2013).

Another fish that is monophyletic is the Oryzias fish group, including $O$. celebensis. According to Mokodongan and Yamahira (2015), these fish are scattered in several areas of Sulawesi (South, West, Central) with various species. Their ancestors are thought to have originated from Asia (Borneo) and were isolated by the opening of the Makassar Strait during the Eocene period, which occurred about 45 million years ago, which resulted in them diverging within the island from a common ancestor (Mandagi et al. 2018).

Information on molecular studies of two other fish species, M. ladigesi and L. micracanthus, is still lacking. Even for L. micracanthus fish, there is no information related to the life history and habitat in which it lives, due to the lack of samples obtained during this research. The phylogenetic placement of these fish in the Terapontidae family is only based on morphological analysis (Vari and Hadiaty 2012). Similar to L. micracanthus fish, M. ladigesi fish also has no information related to DNA barcode analysis. However, DNA barcode analysis of various types of fish from the Telmatherinidae family has been carried out in previous studies (Jayadi et al. 2019). Previously, this fish was described by Ahl (1936) as a type of fish from the Telmatherina genus, namely $T$. ladigesi. Until Aarn et al. (1998) found a clear difference between M. ladigesi fish and other Telmatherina species; they determined it as a genus. Furthermore, this fish is named according to the habitat, namely Maros (Hadiaty 2007).

Many species are endemic to this land with various life challenges due to continuous environmental changes such as pollution, habitat loss, modification and development. Further studies are needed to conserve this native biodiversity and their habitats. Molecular studies have also been used to understand the evolutionary relationships of organisms which are very important in providing insights and establishing appropriate conservation steps (Samsudin 2017).

\section{Conclusion}

In this study, we obtained five endemic fish species from the 
Maros Karst area. These five species represent three orders and four families. These species make particular adaptations both morphologically and genetically to the karst ecosystem. However, it is necessary to understand the evolution of these fishes to establish effective conservation measures.

\section{Acknowledgements}

We would like to thank our research team members of the Maros Karst Region for their participation in the field: Dewi Rahmasari Afrilia Rahim, Dian Julitha, Dwi Sabriyadi Arsal, Mahjati Zatil Ilmi, Nadia Alimah, and Nurwahida. This study was carried out with the assistance of Unhas Basic Research Grants accorded to the corresponding author under contract number 915/UN4.22/PT.01.03/2021.

\section{Author Contributions}

SBAO and DY: proposed the research and finalizing the manuscript, MTU: data collection, AAH and SA: DNA analysis and drafted the manuscript. All authors provided critical feedback and helped to shape the manuscript.

\section{Conflicts of Interest}

The authors declare no conflicts of interest.

\section{Ethics Approval}

Not applicable in this paper

\section{References}

Aarn I, M Kottelat, W Ivantsoff (1998). Phylogenetic analysis of Telmatherinidae (Teleostei: Atherinomorpha) with descriptions of Marosatherina: A new genus from Sulawesi. Ichthyol Explor Freshwat 9:311-323

Abdulmalik-Labe OP, JP Quilang (2019). DNA barcoding of fishes from Lake Lanao, Philippines. Mitochondr DNA B Resour 4:1890-1894

Achmad A, AS Hamzah (2016). Karst Database, South Sulawesi. Badan Lingkungan Hidup Daerah Provinsi Sulawesi Selatan, Indonesia

Ahl E (1936). Beschreibung eines neuen Fisches der Familie Atherinidae aus Celebes. Zool Anzeig 114:175-177

Alotaibi AM, Z Ahmad, M Farooq, HF Albalawi, AF Alrefaei (2020). Phylogenetic analysis of three endogenous species of fish from Saudi Arabia verified that Cyprinion acinaes hijazi is a sub-species of Cyprinion acinaces acinases. J King Saud Univ Sci 32:3014-3017

Andriyono S, MJ Alam, HW Kim (2020). The Jawa and Bali Island marine fish molecular identification to improve $12 \mathrm{~S}$ rRNA-tRNA Valin-16S rRNA partial region sequences on the genbank database. Thalassas 36:343-356

Arsyad M, H Pawitan, P Sidauruk, E Intan, K Putri (2014). Analysis of underground river water availability and its sustainable uses at Karst Maros Area in South Sulawesi). J Manus Lingk 21:8-14

Baldwin CC, JH Mounts, DG Smith, LA Weigt (2009). Genetic identification and color descriptions of early life-history stages of Belizean Phaeoptyx and Astrapogon (Teleostei: Apogonidae) with comments on identification of adult Phaeoptyx. Zootaxa 22:1-22

Bayot FAA, KNA Joya, WR Jacinto (2014). Phylogenetic analysis and barcoding of gobies in Maragondon river, Cavite, Philippines. Intl J Curr Sci 12:50-56
Bichuette ME, E Trajano (2015). Population density and habitat of an endangered cave fish Eigenmannia vicentespelaea Triques, 1996 (Ostariophysi: Gymnotiformes) from a karst area in central Brazil. Neotrop Ichthyol 13:113-122

Bruyn MD, L Rüber, S Nylinder, B Stelbrink, NR Lovejoy, S Lavoué, HH Tan, E Nugroho, D Wowor, PKL Ng, MN Siti Azizah, T Von Rintelen, R Hall, GR Carvalho (2013). Paleo-drainage basin connectivity predicts evolutionary relationships across three southeast asian biodiversity hotspots. Syst Biol 62:398-410

Bucklin A, RR Hopcroft, KN Kosobokova, LM Nigro, BD Ortman, RM Jennings, CJ Sweetman (2010). DNA barcoding of Arctic Ocean holozooplankton for species identification and recognition. Deep-Sea Res Part II: Topical Stud Oceanogr 57:40-48

Çiçek E, R Fricke, S Sungur, S Eagderi (2018). Endemic freshwater fishes of Turkey. FishTaxa 3:1-39

Clark MS, A Tanguy, D Jollivet, F Bonhomme, B Guinand, F Viard (2010). Populations and pathways: Genomic approaches to understanding population structure and environmental adaptation, pp:73-118. In Introduction to Marine Genomics. Cock JM, K Tessmar-Raible, C Boyen, F Viard (Eds). Springer, Dordrecht, The Netherlands

Dekić R, A Ivanc, S Lolic, B. Jelena, S Obradovic, D Cetkovic (2015). The recent state of distribution of endemic fish species in Eastern Herzegovina, pp:195-199. In: International Conference on Aquaculture \& Fishery. Faculty of Agriculture, Belgrade-Zemun, Serbia

Hadiaty RK (2012). Fish. In: Fauna of Karst and Cave of Maros, South Sulawesi, pp:89-113. Suhardjono YR, R Ubaidillah (Eds). Lembaga Ilmu Pengetahuan Indonesia, Cibinong, Bogor, Indonesia

Hadiaty RK (2017). Ichthyofauna of Menoreh Karst area, Jawa Tengah and the conservations efforts. J Iktiol Ind 16:199-210

Hadiaty RK (2007). Scientific review of a rainbow fish Marosatherina ladigesi (Ahl 1936) an endemic fauna of Sulawesi. Berit Biol $8: 473-479$

Hamaguchi S (1983). Asymmetrical development of the gonads in the embryos and fry of the fish, Oryzias celebensis. Dev Growth Different 25:553-561

Hanly PJ, GG Mittelbach, DW Schemske (2017). Speciation and the latitudinal diversity gradient: Insights from the global distribution of endemic fish. Amer Nat 189:604-615

HasanahN, SBA Omar, J Tresnati, MS Nurdin (2019). Length at first maturity of Indonesian endemic medaka fish. J Ilmiah Samudr Akuat 3:31-35

Hebert PDN, S Ratnasingham, JD Waard (2003). Barcoding animal life: Cytochrome $\mathrm{c}$ oxidase subunit 1 divergences among closely related species. Proc Royal Soc B Biol Sci 270:96-99

Hubert N, Kadarusman, A Wibowo, F Busson, D Caruso, S Sulandari, N Nafiqoh, L Pouyaud, L Rüber, JC Avarre, F Herder, R Hanner, P Keith, RK Hadiaty (2016). DNA Barcoding Indonesian freshwater fishes: challenges and prospects. DNA Barcod 3:144-169

In DS, ES Choi, JD Yoon, JH Kim, JIl Min, SH Baek, MH Jang (2013). Cytochrome oxidase subunit I (COI) DNA sequence divergence between two cryptic species of Oryzias in South Korea. J Ecol Environ 36:159-166

Jayadi J, I Ilmiah, S Hadijah, M Kasnir, DI Roslim (2019). DNA barcoding of Telmatherinidae family in Lake Towuti, South Sulawesi, Indonesia. AACL Biofl 12:1208-1215

Jayadi J, A Tamsil, S Hadijah (2015). Study of genetic variation of besengbeseng fish (Telmatherina ladigesi) from south sulawesi using the random amplified polymorphism DNA method (RAPD). In: Prosiding Seminar Nasional Mikrobiologi Kesehatan dan Lingkungan, pp:21-27. UIN Alaudin Makassar, Indonesia

Kariyanti K, SBA Omar, J Tresnati (2019). Macroscopic and microscopic identification of the gonad maturity level of the endemic beseng-beseng fish (Marosatherina ladigesi Ahl, 1936). Agrok J Teknol Perik Perkeb Agrib 19:45-50

Kobayashi H, KWA Masengi, K Yamahira (2020). A new “"beakless" halfbeak of the genus Nomorhamphus from Sulawesi (Teleostei: Zenarchopteridae). Copeia 108:522-531

Kolda A, I Mujakić, L Perić, I Vardić Smrzlić, D Kapetanović (2020). Microbiological quality assessment of water and fish from kars rivers of the southeast Black Sea basin (Croatia), and antimicrobial susceptibility of Aeromonas isolates. Curr Microbiol 77:2322-2332 
Kottelat M, AJ Whiten, S Kartikasari, SN Wirjoatmodjo (1993). Freshwater Fishes of Western Indonesia and Sulawesi. Collaboration with the Envinmental Management Development ini Indonesia (EMDI) Project Ministry of State for Population and Environment, Periplus Editions (HK) Ltd. Republic of Indonesia

Kumar S, G Stecher, K Tamura (2016). MEGA7: Molecular Evolutionary Genetics Analysis Version 7.0 for Bigger Datasets. Mol Biol Evol 33:1870-1874

Larson HK, MF Geiger, RK Hadiaty, F Herder (2014). Mugilogobius hitam, a new species of freshwater goby (Teleostei: Gobioidei: Gobiidae) from Lake Towuti, central Sulawesi, Indonesia. Raffl Bull Zool 62:718-725

Lefébure T, CJ Douady, M Gouy, J Gibert (2006). Relationship between morphological taxonomy and molecular divergence within Crustacea: Proposal of a molecular threshold to help species delimitation. Mol Phylogenet Evol 40:435-447

Madden T (2013). The BLAST sequence analysis tool, pp:1-17. The NCBI Handbook, $2^{\text {nd }}$ edn. Bethesda, Maryland, USA

Malabarba LR, MC Malabarba (2020). Phylogeny and classification of neotropical fish. In: Biology and Physiology of Freshwater Neotropical Fish, pp:1-19. Baldiserotto B, EC Urbinati, JEP Cyrino (Eds). Academic Press, London

Mandagi IF, DF Mokodongan, R Tanaka, K Yamahira (2018). A new riverine ricefish of the genus Oryzias (Beloniformes, Adrianichthyidae) from Malili, Central Sulawesi, Indonesia. Copeia 106:297-304

Mokodongan DF, K Yamahira (2015). Origin and intra-island diversification of Sulawesi endemic Adrianichthyidae. Mol Phylogenet Evol 93:150-160

Naim D, HAM Rosly, SAM Nor (2012). Assessment of phylogenetic interrelationships in mud crab genus Scylla (Portunidae) based on mitochondrial DNA sequence, pp:269-275. In: International Conference on Applied Life Sciences (ICALS2012), September 10 12, 2012, Turkey

Nasyrah AFA, MF Rahardjo, CPH Simanjuntak (2020). Reproduction of Celebes rainbowfish, Marosatherina ladigesi Ahl, 1936 in Pattunuang and Batu Puteh Rivers, South Sulawesi. J Iktiol Indo 20:171-188

Nasyrah AFA, MF Rahardjo, CPH Simanjuntak (2019). Ecobiology of Celebes rainbowfish (Marosatherina ladigesi Ahl, 1963) endemic in South Sulawesi: A literature review. In: SNIP2D Jambi, pp:17-27

Nur M, MF Rahardjo, CP Simanjuntak, D Djumanto, K Krismono (2020a). Length-weight relationship and condition factor of an endemic Lagusia micracanthus Bleeker 1860 in rivers of the Maros watershed. J Iktiol Ind 20:263-270
Nur M, MF Rahardjo, CPH Simanjuntak, Djumanto, K Krismono (2020b). Morphometric and meristic of an endemic fish Lagusia micracanthus Bleeker 1860 in the rivers of Maros and Wallanae Cenrana watersheds. J Iktiol Ind 20:189-203

Nur M, SBA Omar, J Tresnati, MA Dahlan, Suwarni (2016). Morphological analysis of the gonad maturity level of the endemic pirik fish (Lagusia micracanthus Bleeker 1860) in the Pattunuang River, South Sulawesi. In: Prosiding Simposium Nasional III Kelautan dan Perikanan. Makassar, Indonesia, pp:249-253

Omar SBA (2012). The World of Fish. GadjahMada University Press, Yogyakarta, Indonesia

Omar SBA, K Kariyanti, D Yanuarita, MT Umar, YSA Lawi (2020). Length-weight relationship and condition factor of the Celebes rainbowfish Marosatherina ladigesi, endemic to the Maros karst region, South Sulawesi, Indonesia. AACL Bioflux 13:3384-3396

Omar SBA, M Nur, MT Umar, M Dahlan, S Kune (2015). Sex ratios and size at sexual maturity of pirik (Lagusia micracanthus Bleeker 1860) endemic fish in Pattunuang River, Maros District and Sanrego River, Bone District, South Sulawesi, p:13. In: Prosiding Seminar Nasional Tahunan XII Hasil Penelitian Perikanan dan Kelautan, Makassar, Indonesia,

Omar SBA, K Kariyanti, J Tresnati, MT Umar, S Kune (2014). Sex ratios and size at sexual maturity of beseng-beseng Marosatherina ladigesi (Ahl 1936) endemic fish in Pattunuang Asue River and Bantimurung River, Maros District, South Sulawesi, p:8. In: Prosiding Seminar Nasional Tahunan XI Hasil Penelitian Perikanan dan Kelautan, Makassar, Indonesia

Putri IASLP, F Ansari, A Susilo (2020). Response of bird community toward tourism activities in the karst area of Bantimurung Bulusaraung National Park. J Qual Assur Hosp Tour 21:146-167

Samsudin NF (2017). DNA Barcoding, phylogenetics and phylogeography of freshwater halfbeak genus Dermogenys (Kuhl and van Hasselt 1823) in Sundaland River Basin. Ph.D. Dissertation. University Sains Malaysia, George Town, Penang, Malaysia

Serdiati N, D Arfiati, MS Widodo, TJ Lelono, S Ndobe, R Saranga (2020). Morphological variations and phylogenetic analysis of Oryzias nigrimas Kottelat, 1990 (Rice fish) from Lake Poso, Central Sulawesi, Indonesia. Biodiversitas 21:882-888

Suhendar AS, E Yani, P Widodo (2018). Vegetation analysis of the South Gombong Karst Area, Kebumen, Central Java. Scrip Biol 5:37-40

Taslim I (2014). Hydrogeology characteristics of Maros karst region: Case study Saleh cave at Patunuangasue area, Simbang District. Hasanuddin University, Makassar, Indonesia

Vari RP, RK Hadiaty (2012). The endemic Sulawesi fish genus Lagusia (Teleostei: Terapontidae). Raffl Bull Zool 60:157-162 